\title{
Penggunaan Tepung Limbah Udang sebagai Bahan Pakan Sumber Protein terhadap Performa Produksi Puyuh Fase Layer (Coturnix-coturnix japonica)
}

\author{
Hamdan Has $^{1 *}$, Astriana Napirah ${ }^{1}$, Widhi Kurniawan ${ }^{1}$, Natsir Sandiah ${ }^{1}$ \\ ${ }^{1}$ Jurusan Peternakan, Fakultas Peternakan Universitas Halu Oleo \\ Jl. H.E.A. Mokodompit Kampus Hijau Bumi Tridharma, Anduonohu, Kendari 93232 \\ *Email korespondensi: hamdan_has@uho.ac.id
}

(Diterima: 16-8-2018; disetujui 20-9-2018)

\begin{abstract}
ABSTRAK
Limbah udang merupakan limbah pengolahan udang yang memiliki potensi sebagai pakan sumber protein bagi ternak puyuh. Penelitian ini bertujuan mengkaji penggunaan tepung limbah udang (TLU) sebagai sumber protein pakan pada puyuh fase layer. Penelitian ini menggunakan rancangan acak lengkap empat perlakuan lima ulangan perlakuan yang digunakan terdiri dari empat level penggunaan tepung limbah udang dalam ransum yaitu P0 (kontrol), P1 (5\% TLU), P2 (7,5\% TLU) dan P3 (10\% TLU), tiap unit perlakuan disi dengan 5 ekor puyuh. Puyuh yang diguanakan adalah puyuh fase layer umur 20 minggu, sebanyak 100 ekor yang didistribusikan kedalam 20 unit percobaan. Bahan pakan yang digunakan adalah jagung, dedak padi, konsentrat petelur dan tepung limbah udang. Data yang diperoleh dianalisis ragam dan data yang berbeda nyata $(\mathrm{P}<0,05)$ diuji lanjut menggunakan uji duncan. Variabel yang diamati adalah performa produksi: konsumsi pakan, produksi telur, bobot telur dan konversi ransum. Hasil penelitian menunjukkan bahwa penggunaan TLU dalam ransum $(\mathrm{P} 1, \mathrm{P} 2$ dan $\mathrm{P} 3)$ menunjukkan pengaruh nyata $(\mathrm{P}<0,05)$ dibanding kontrol pada minggu ke-tiga penelitian terhadap bobot telur dan konversi ransum, penggunaan TLU (P1,P2,P3) selama lima minggu meningkatkan konsumsi ransum $(\mathrm{P}<0,05)$ dibanding kontrol tetapi tidak berbeda nyata $(\mathrm{P}>0,05)$ terhadap produksi telur, bobot telur dan konversi ransum. Kesimpulan penelitian ini bahwa penggunaan TLU dalam ransum dapat digunakan hingga level 7,5\% sedangkan level $10 \%$ menunjukkan adanya penurunan rata-rata performa produksi.
\end{abstract}

Kata kunci: tepung limbah udang, puyuh fase layer, performa produksi

\begin{abstract}
Shrimp waste was shrimp processing waste which has the potential as protein source for quail feed. This study was aimed to examine the use of shrimp waste flour (SWF) asprotein source for laying quail feed. This study used completely randomized design that consist of four treatments and five replications.The treatmentswere using levels of shrimp waste flour in feed and consist of P0 (control), P1 (5\% SWF), P2 (7.5\% SWF) and P3 (10\% SWF ). Each treatment unit was filled with 5 quails. One hundred of 20 weeks laying quails were used in this study. Self mixing feed that contained corn, rice bran, laying concentrate and shrimp waste flour were used in this study. The data obtained were analyzed using analyze of variance and continued using Duncan multiple range test. The variables observed were production performance that consist of feed consumption, egg production, egg weight and feed conversionratio. The results showed that the use of SWF in feed (P1, P2 and P3) showed a significant effect $(\mathrm{P}<0.05)$ compared to controls in the third week of research on egg weight and feed conversion ratio.The use of SWF (P1, P2, P3) for five weeks increased feed consumption (P $<0.05)$ compared to controls but not significantly different $(\mathrm{P}>0.05)$ for egg production, egg weight and feed conversion. The conclusion of this study was the use of SWF in feed can be used until $7.5 \%$ on laying quail feed while the level of $10 \%$ indicates a decrease in average production performance.
\end{abstract}

Keywords: shrimp waste flour, laying quail, production performance 


\section{PENDAHULUAN}

Puyuh merupakan salah satu ternak yang telah banyak diusahakan di Indonesia, termasuk Sulawesi Tenggara. Puyuh banyak digemari karena memiliki produktivitas tinggi dan tidak memerlukan lahan yang luas dalam pemeliharaannya. Puyuh dapat dikembangkan baik untuk tujuan produksi telur maupun daging. Daging dan telur puyuh diketahui memiliki nilai nutrisi yang tinggi (Genchev et al., 2008; Genchev, 2012).

Salah satu permasalahan yang dialami peternak puyuh di daerah Sulawesi Tenggara adalah terbatasnya pakan komersil bagi ternak puyuh di pasaran. Harga pakan komersil yang fluktuatif dan relatif mahal juga menjadi salah satu faktor yang mempengaruhi pendapatan peternak puyuh (Panekanan, 2013; Lainawa, 2015). Mengatasi masalah tersebut, perlu dilakukan pembuatan pakan puyuh dengan memanfaatkan bahan pakan potensial yang harganya terjangkau dan ketersediaannya terjaga sepanjang waktu. Salah satu bahan pakan potensial digunakan sebagai pakan ternak puyuh adalah limbah udang. Limbah udang merupakan limbah industri perikanan yang masih memiliki nilai nutrisi (Saenab et al., 2010). Melalui teknik pengolahan yang tepat, limbah udang dapat digunakan sebagai bahan pakan unggas (Palupi dan Imsya, 2011; Djunaidi dan Hardini, 2010). Sahara (2011) melaporkan bahwa pemberian tepung kepala udang dalam pakan itik petelur secara nyata mempengaruhi warna telur dan memperbaiki konversi ransum.

Berdasarkan uraian tersebut, maka dilakukan penelitian yang mempelajari bagaimana pengaruh pemberian pakan yang mengandung limbah kulit udang terhadap produktivitas puyuh petelur.

\section{MATERI DAN METODE}

Seratus ekor puyuh fase layer digunakan dalam penelitian ini. Ternak puyuh ditempatkan dalam 20 unit kandang percobaan. Masingmasing unit kandang berukuran 30x30x30 cm dan diisi 5 ekor puyuh. Alat yang digunakan dalam penelitian ini adalah tempat pakan dan air minum puyuh, timbangan digital, terpal, blender, baskom.

Bahan pakan yang digunakan adalah jagung kuning, dedak padi, konsentrat layer dan limbah udang. Limbah udang diperoleh dari industri pengolahan udang di Kota Kendari. Limbah udang dikumpulkan, kemudian dikeringkan di bawah sinar matahari selama 2 hari. Setelah kering, limbah udang dihaluskan menggunakan mesin penepung. Tepung limbah udang yang dihasilkan siap untuk digunakan dalam pembuatan pakan puyuh.

Penelitian ini menggunakan rancangan acak lengkap empat perlakuan dan lima ulangan. Perlakuan yang dicobakan adalah penambahan tepung kulit udang dengan level berbeda di dalam pakan puyuh. Data yang diperoleh dianalisis menggunakan analisis ragam. Data yang terdapat pengaruh nyata, diuji lanjut menggunakan uji Duncan (Duncan Multiple Range Test)

Perlakuan dalam penelitian ini adalah P0: Pakan tanpa tepung limbah udang; P1: Pakan yang mengandung 5\% tepung limbah udang; P2 : Pakan yang mengandung 7,5\% tepung limbah udang; dan P3: Pakan yang mengandung 10\% tepung limbah udang.

Variabel yang diamati adalah konsumsi ransum, produksi telur (quail day production), bobot telur dan konversi ransum. Pakan perlakuan yang digunakan adalah pakan self mixing yang disusun dari konsentrat layer, jagung giling, dedak padi, dan limbah udang. Secara rinci komposisi dan kadar nutrisi ransum perlakuan ditampilkan pada Tabel 1 .

Tabel 1. Komposisi dan kadar nutrien ransum perlakuan

\begin{tabular}{lcccc}
\hline \multirow{2}{*}{ Bahan Pakan } & \multicolumn{4}{c}{ Perlakuan } \\
\cline { 2 - 5 } & P0 & P1 & P2 & P3 \\
\hline Jagung & 50 & 50 & 51,5 & 52 \\
Dedak & 15 & 14 & 13 & 12 \\
Tepung limbah udang & 0 & 5 & 7,5 & 10 \\
Konsentrat layer & 35 & 31 & 28 & 26 \\
\hline Jumlah & 100 & 100 & 100 & 100 \\
\hline \multicolumn{4}{c}{ Kadar Nutrien Ransum Perlakuan } \\
\hline EM(Kkal/kg) & 3096 & 3047 & 3032 & 3016 \\
PK (\%) & 18,9 & 18,95 & 18,65 & 18,63 \\
LK (\%) & 5,28 & 5,14 & 5,0 & 4,9 \\
SK (\%) & 5,95 & 6,6 & 6,82 & 7,08 \\
\hline
\end{tabular}

Sebelum dilakukan koleksi data, terlebih dahulu dilakukan tahap adaptasi pakan selama 1 minggu. Adaptasi pakan dimaksudkan untuk membiasakan ternak puyuh dengan pakan percobaan. Setelah masa adaptasi selesai, maka dilakukanlah proses koleksi data selama 5 minggu. Pakan percobaan dan air minum diberikan secara ad libitum. Pengumpulan telur dilakukan 2 kali sehari, yaitu pada pagi pukul 09.00 dan sore hari pukul 17.00. Telur yang dikumpulkan kemudian langsung ditimbang. Pengukuran konsumsi pakan dan produksi telur puyuh juga dilakukan setiap hari 
Tabel 2. Performa produksi telur puyuh pada setiap minggu

\begin{tabular}{|c|c|c|c|c|c|}
\hline Parameter/ perlakuan & Minggu 1 & Minggu 2 & Minggu 3 & Minggu 4 & Minggu 5 \\
\hline Quail day Production & \multicolumn{5}{|c|}{ |------------------------------------------- \% ---------------------------------------------------- } \\
\hline $\mathrm{P} 0$ & $81.8 \pm 5,54$ & $84,80 \pm 9,90$ & $81,80 \pm 4,49$ & $82,40 \pm 2,88$ & $83,00 \pm 3,08$ \\
\hline $\mathrm{P} 1$ & $84.6 \pm 2,88$ & $83,20 \pm 5,54$ & $79,60 \pm 3,91$ & $78,80 \pm 3,70$ & $82,00 \pm 0,00$ \\
\hline $\mathrm{P} 2$ & $85,00 \pm 4,94$ & $80,40 \pm 3,91$ & $79,20 \pm 3,83$ & $82,60 \pm 6,34$ & $81,60 \pm 3,50$ \\
\hline P3 & $82,00 \pm 0,00$ & $79,60 \pm 2,19$ & $76,80 \pm 1,64$ & $79,60 \pm 3,91$ & $80,20 \pm 4,54$ \\
\hline Konsumsi Ransum & \multicolumn{5}{|c|}{------------------------------------- g/ekor/hari------------------------------------------- } \\
\hline $\mathrm{P} 0$ & $27,91^{\mathrm{a}} \pm 0,54$ & $27,99^{\mathrm{a}} \pm 0,12$ & $28,01^{\mathrm{a}} \pm 0,09$ & $28,01^{\mathrm{a}} \pm 0,09$ & $27,00^{\mathrm{a}} \pm 0,11$ \\
\hline $\mathrm{P} 1$ & $28,00^{\mathrm{b}} \pm 0,44$ & $28,12^{\mathrm{b}} \pm 0,03$ & $28,15^{\mathrm{b}} \pm 0,05$ & $28,15^{\mathrm{ab}} \pm 0,05$ & $28,13^{\mathrm{b}} \pm 0,55$ \\
\hline $\mathrm{P} 2$ & $28,04^{\mathrm{bc}} \pm 0,05$ & $28,19^{\mathrm{bc}} \pm 0,02$ & $28,22^{\mathrm{bc}} \pm 0,94$ & $28,22^{\mathrm{bc}_{ \pm}} \pm 0,06$ & $28,16^{\mathrm{bc}} \pm 0,86$ \\
\hline P3 & $28,10^{\mathrm{c}} \pm 0,02$ & $28,29^{c} \pm 0,08$ & $28,30^{\mathrm{c}} \pm 0,05$ & $28,29^{c} \pm 0,06$ & $28,28^{c} \pm 0,66$ \\
\hline Bobot Telur & \multicolumn{5}{|c|}{ 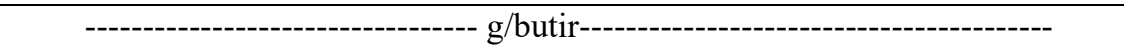 } \\
\hline $\mathrm{P} 0$ & $10,02 \pm 0,58$ & $10,51 \pm 1,16$ & $10,36^{\mathrm{a}} \pm 0,69$ & $10,36 \pm 0,34$ & $10,43 \pm 0,38$ \\
\hline P1 & $10,37 \pm 0,74$ & $10,30 \pm 0,64$ & $9,95^{\mathrm{ab}} \pm 0,45$ & $10,09 \pm 0,35$ & $10,25 \pm 0,02$ \\
\hline $\mathrm{P} 2$ & $10,46 \pm 0,61$ & $10,20 \pm 0,37$ & $9,93^{\mathrm{ab}} \pm 0,43$ & $10,34 \pm 0,75$ & $10,26 \pm 0,41$ \\
\hline P3 & $9,95 \pm 0,24$ & $9,93 \pm 0,23$ & $9,68^{\mathrm{b}} \pm 0,26$ & $10,03 \pm 0,49$ & $10,10 \pm 0,57$ \\
\hline \multicolumn{6}{|l|}{ Konversi ransum } \\
\hline $\mathrm{P} 0$ & $2,79 \pm 0,16$ & $2,68 \pm 0,16$ & $2,64^{\mathrm{a}} \pm 0,16$ & $2,7 \pm 0,09$ & $2,68 \pm 0,10$ \\
\hline $\mathrm{P} 1$ & $2,71 \pm 0,18$ & $2,83 \pm 0,12$ & $2,83^{\mathrm{ab}} \pm 0,12$ & $2,7 \pm 0,09$ & $2,74 \pm 0,08$ \\
\hline $\mathrm{P} 2$ & $2,68 \pm 0,16$ & $2,84 \pm 0,13$ & $2,84^{\mathrm{b}} \pm 0,13$ & $2,73 \pm 0,19$ & $2,74 \pm 0,11$ \\
\hline P3 & $2,82 \pm 0,06$ & $2,92 \pm 0,16$ & $2,92^{\mathrm{b}} \pm 0,07$ & $2,82 \pm 0,12$ & $2,80 \pm 0,11$ \\
\hline
\end{tabular}

Keterangan :Superscrib berbeda pada kolom dan parameter yang sama menunjukkan perbedaan nyata $(\mathrm{P}<0,05)$

\section{HASIL PENELITIAN}

\section{Konsumsi ransum}

Hasil analisis ragam menunjukkan penggunaan tepung cangkang udang berpengaruh nyata $(\mathrm{P}<0,05)$ terhadap konsumsi ransum puyuh fase layer. Data penelitian menunjukkan bahwa perlakuan berpengaruh disetiap minggu pemeliharaan, penggunaan tepung limbah udang dalam ransum dapat meningkatkan konsumsi ransum mulai dari P1 hingga $\mathrm{P} 3$ dibanding kontrol (P0). Hal ini mengindikasikan bahwa penggunaan TLU dalam ransum dapat meningkatkan palatabilitas ransum yang diduga disebabkan oleh perubahan warna, bau, dan rasa. Mahata et al. (2008) menyatakan bahwa konsumsi ransum dapat diperngaruhi oleh perubahan warna pakan dan rasa serta bau pakan. Peningkatan konsumsi mulai dari minggu pertama hingga minggu kelima penelitian diduga disebabkan tingginya serat kasar dan kitin pada tepung limbah udang sehingga peningkatan persentase dalam ransum ikut berdampak pada peningkatan total serat kasar ransum. Peningkatan serat kasar dalam ransum akan meingkatkan laju digesta dalam usus sehingga pakan cepat keluar dari saluran pencernaan sehingga ternak akan merasa lapar dan terus mengkonsumsi ransum (Has et al., 2013; Bidura, 2007; Ironkwe \& Oruwari, 2012). Purnawati (1997) menambahkan bahwa khitin termasuk kedalam kelompok serat dari hewan yang memiliki struktur mirip selulosa dengan kadar total serat kasar $72.52 \%$ sehingga dikelompokkan kedalam makanan dengan kadar serat tinggi. Hasil penelitian ini tidak sejalan dengan penelitian Bakri et al. (2011) yang menyatakan peningkatan tepung cangkang udang dalam ransum menurunkan konsumsi ransum pada puyuh grower. Rata rata konsumsi puyuh fase layer dalam penelitian ini berkisar antara 27-28 g/ekor/hari, hasil ini lebih tinggi dibanding yang dilaporkan oleh Francela et al. (2017) bahwa konsumsi puyuh fase layer berkisar antara20-23 $\mathrm{g} /$ ekor/hari dan ditambahkan oleh Sudrajat et al. (2014) konsumsi pakan puyuh berkisar antara 18$20 \mathrm{~g} / \mathrm{ekor} / \mathrm{hari}$.

\section{Produksi Telur/ Quail Day Production (QDP)}

Berdasarkan hasil analisis ragam terhadap data penelitian tidak terdapat perbedaan nyata $(\mathrm{P}>0,05)$ antara perlakuan kontrol dan penggunaan tepung limbah udang. Penggunaan tepung limbah udang hingga 10\% dalam ransum puyuh fase layer tidak menyebabkan dampak penurunan produksi 


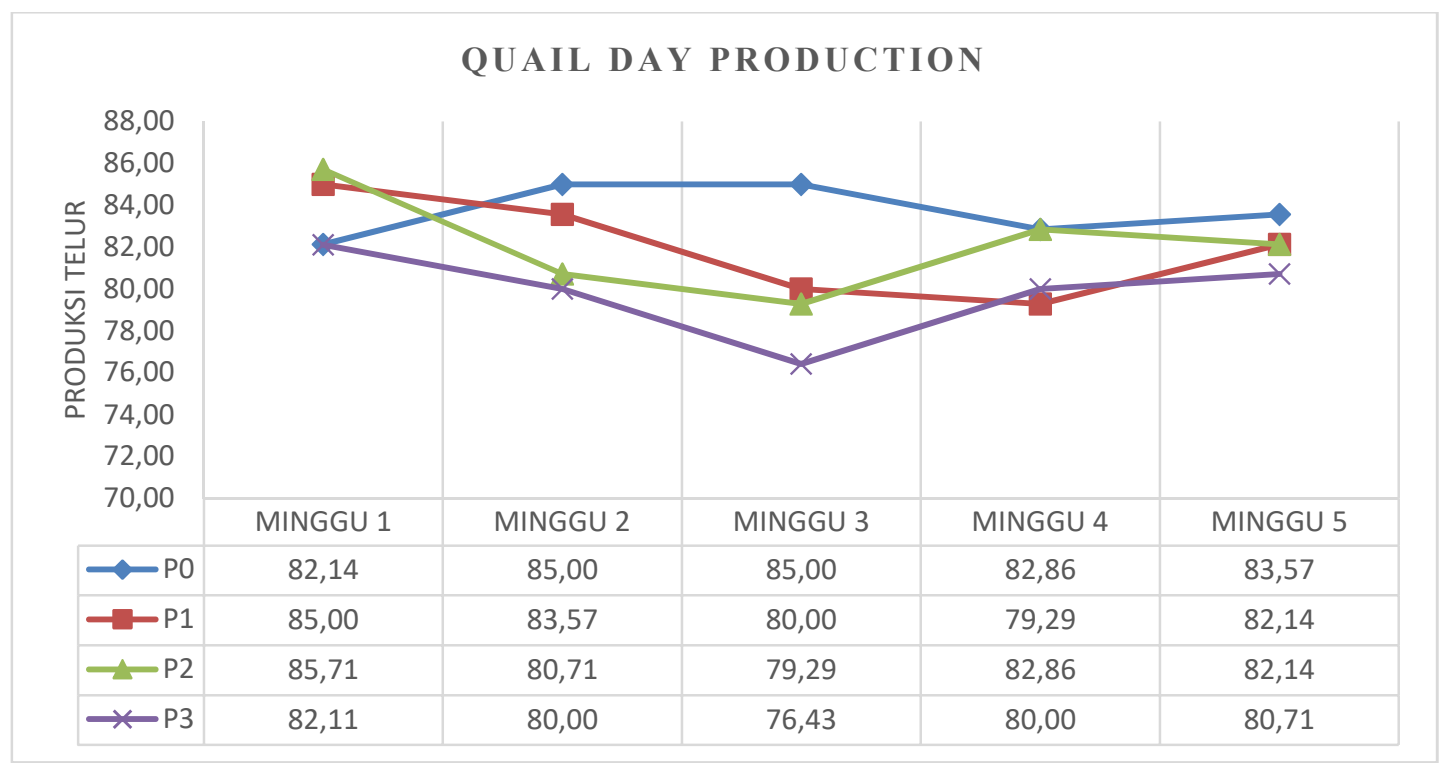

Gambar 1. Grafik produksi telur puyuh yang diberi tepung limbah udang dalam ransum

yang signifikan. Tepung limbah udang mengandung protein kasar 35,3\%-52,7\% (Gernat, 2001; Dong et al.,2005) sehingga penggunaannya dalam ransum dapat menggantikan sebagian sumber protein utama dalam ransum seperti konsentrat.

Hasil pengamatan selama lima minggu menunjukkan bahwa penggunaan tepung limbah udang sedikit menunjukan tren penurunan produksi di minggu awal (Gambar 1), penurunan mulai terjadi pada minggu pertama hingga minggu ke tiga dan kembali mengalami kenaikan produksi pada minggu ke empat dan minggu ke lima. Tren penurunan produksi ini diduga terjadi akibat adaptasi ransum oleh puyuh dan kembali melakukan penyesuaian yang ditandai dengan tren peningkatan produksi pada minggu ke empat dan lima.Produksi telur pada penelitian ini berkisar antara $76-85 \%$, hasil ini lebih tinggi dibandingkan produksi telur harian yang dilaporkan oleh Fransela et al (2017) bahwa produksi telur puyuh layer berkisar 60\%-61\% dan Ratrianto (2018) berkisar 68-78\%.

\section{Bobot Telur}

Hasil analisis data penelitian terhadap parameter bobot telur rata rata selama penelitian menunjukkan bahwa penggunaan tepung limbah udang dalam ransum puyuh fase layer tidak berbeda nyata $(\mathrm{P}>0,05)$ pada minggu ke $1,2,4$ dan 5 tetapi berbeda nyata $(\mathrm{P}<0,05)$ pada bobot telur minggu ke 3 . Pada minggu ke tiga perlakuan terlihat bahwa penggunaan tepung limbah udang terutama $10 \%$ dalam ransum memiliki bobot telur yang lebih kecil dibanding kontrol. Hal ini diduga disebabkan pengaruh serat kasar yang tinggi pada tepung limbah udang sehingga mengurangi tingkat kecernaan ransum dan berdampak pada bobot telur yang dihasilkan menjadi lebih kecil. Hal ini sesuai pendapat Has et al. (2013) bahwa serat kasar yang meningkat dalam ransum akan menurunkan kecernaan nutrien lain. Pada minggu ke empat dan ke lima penelitian, kembali terjadi peningkatan bobot telur yang diduga akibat kemampuan dari puyuh untuk beradaptasi dengan pakan yang dikonsumsi. Hasil ini (minggu 1, 2, 4, dan 5) menunjukkan bahwa penggunaan tepung limbah udang hingga $10 \%$ dalam ransum tidak berpengaruh terhadap bobot telur puyuh, hal serupa dilaporkan oleh Juliambarwati et al. (2012) bahwa penggunaan tepung limbah udang hingga $9 \%$ tidak berpengaruh terhadap bobot telur itik.

\section{Konversi Ransum}

Data konversi ransum hasil penelitian yang telah dianalisis ragam menunjukkan tidak terdapat perbedaan nyata $(\mathrm{P}>0,05)$ pada minggu $1,2,4$, dan 5 tetapi terdapat perbedaan nyata $(\mathrm{P}<0,05)$ pada minggu ke 3 . Pada minggu ke tiga, rata rata konversi ransum perlakuan yang menggunakan tepung limbah udang mengalami peningkatan konversi ransum dibanding control, hal ini diduga tepung limbah udang mengandung khitin dan serat kasar yang tinggi sehingga peningkatan penggunaan dalam ransum berdampak pada kecernaan nutrien lainnya sehingga menurunkan efesiensi ransum. Oduguwa et al. (2004) melaporkan bahwa subtitusi limbah udang terhadap sumber protein 
utama dalam ransum unggas seperti tepung ikan dan bungkil kedelai dapat menurunkan performa. Limbah udang mengandung chitin, dalam bentuk $\mathrm{N}$-acetylated glucosamine polysaccharide merupakan bentuk protein kompleks, dan diyakini memiliki kecernaan yang rendah jika diberikan sebagai pakan terhadap ternak (Gernat, 2001).

Hasil penelitian menunjukkan bahwa penggunaan tepung limbah udang menyebabkan peningkatan konversi ransum, hal serupa dilaporkan (Gernat, 2001) bahwa penggunaan limbah udang relatif meningkatkan konversi ransum pada ayam petelur. Ditambahkan oleh Mahata et al. (2008) bahwa penggunaan tepung limbah udang pengganti tepung ikan meningkatkan konversi ransum pada ayam broiler. Penggunaan limbah udang dalam ransum diduga dapat ditingkatkan kecernaanya dengan beberapa tehnik perlakuan pakan seperti penambahan $\mathrm{NaOH}$ (Puspawati dan Simpen, 2010), fermentasi (Palupi \& Imsya, 2011), dan hidrolisis. Mahata et al. (2008) melaporkan perlakuan hidrolisis dapat menurunkan serat kasar, meningkatkan protein kasar dan energi metabolis limbah udang.

\section{KESIMPULAN}

Penggunaan tepung limbah udang dalam ransum puyuh fase layer dapat digunakan sebanyak $10 \%$ dalam ransum puyuh, tetapi untuk memaksimalkan penggunaanya perlu diteliti lebih lanjut mengenai tepung limbah udang yang diberi perlakuan pengolahan pakan.

\section{DAFTAR PUSTAKA}

Bakrie, B., E. Manshur, \& I.M. Sukadana. 2011. Pemberian berbagai level tepung cangkang udang ke dalam ransum anak puyuh dalam masa pertumbuhan (umur 1-6 minggu). Jurnal Penelitian Pertanian Terapan 12 (1):58-68

Bidura, I.G.N.G. 2007. Aplikasi Produk Bioteknologi Pakan Ternak. UPT Penerbit Universitas Udayana. Denpasar.

Djunaidi, I.H. \& D. Hardini. 2010. Kandungan nutrien dan kecernaan bahan kering invitro limbah udang hasil fermentasi dengan Aspergillus oryzae. Jurnal IlmuIlmu Peternakan 20(2):31-35.

Dong, N.T.K., K. Elwinger, J.E. Lindberg \& R.B. Ogle. Effect of replacing soybean meal with soya waste and fish meal with ensiled shrimp waste on the performance of growing crossbred ducks. Asian-Aust. J. Anim. Sci. 18 (6):825-834

Fransela, T., Ch.L.K. Sarajar, M.E.R. Montong, $\&$ M. Najoan. 2017. Performans burung puyuh (Coturnix-coturnix japonica) yang diberikan tepung keong sawah (Pila ampullacea) sebagai pengganti tepung ikan dalam ransum. Jurnal Zootek 37(1): 62-69.

Genchev, A., G. Mihaylova, S. Ribarski, A. Pavlov, \& M. Kabakchiev. 2008. Meat quality and composition in japanese quails. Trakia Journal of Science 6(4):7282.

Genchev, A. 2012. Quality and composition of japanese quail eggs (Coturnix japonica). Trakia Journal of Science 10(2):91-101.

Gernat, A. G. 2001. The Effect of using different levels of shrimp meal in laying hen diets. Poultry Science 80:633-636.

Has, H., V.D. Yunianto, \& B. Sukamto.2013. Kecukupan energi pakan yang menggunakan daun murbei (Orus alba) fermentasi melalui pengukuran glukosa, lemak abdominal dan konsumsi ransum. JITP 3(1):13-24.

Has, H., V.D. Yunianto \& B. Sukamto. 2013. The effectivity of fermented mulberry leaves with rumen liquor as broiler feed on final body weight, dry matter and crude fiber digestibility, and metabolic energy. Animal Production 15(3):173179.

Ironkwe, M.O. \& B.M. Oruwari. 2012. Effect of replacement levels of maize with plantain peel in broiler finisher diet. Bulletin of Environment, Pharmacology \& Life Sciences 1(4):39-42.

Juliambarwati, M., A. Ratriyanto \& A. Hanifa. 2012. Pengaruh penggunaan tepung limbah udang dalam ransum terhadap kualitas telur itik. Sains Peternakan 10(1):1-6.

Lainawa, J., N.M. Santa, J. Pandey, \& B. Bagau. 2015. Pemanfaatan sumberdaya lokal sebagai bahan baku industri dan pakan alternatif dalam meningkatkan pendapatan ternak puyuh organik di Kecamatan Sonder, Kabupaten Minahasa. Prosiding Seminar Nasional Masyarakat 
Biodiversitas Indonesia, Depok, 20 Desember 2014, 1(2):383-387.

Mahata, M.E., A. Dharma, H.I. Ryanto, \& Y. Rizal. 2008. Effect of substituting shrimp waste hydrolysate of penaeus merguensis for fish meal in broiler performance. Pakistan Journal of Nutrition 7(6):806-810.

Oduguwa, O.O., A.O. Fanimo, V.O. Olayemi \& N. Oteri . 2004. The feeding value of sun-dried shrimp waste-meal based diets for starter and finisher broilers. Arch. Zootec. 53: 87-90.

Palupi, R. \& A. Imsya. 2011. Pemanfaatan kapang Trichoderma viridae dalam proses fermentasi untuk meningkatkan kualitas dan daya cerna protein limbah udang sebagai pakan ternak unggas. Prosiding Seminar Nasional Teknologi Peternakan dan Veteriner 2011. Bogor, 7-8 Juni 2011. Hlm. 672-677.

Panekanan, J.O., J.C. Loing, B. Rorimpandey, \& P.O.V. Waleleng. Analisis keuntungan usaha beternak puyuh di Kecamatan Sonder Kabupaten Minahasa. Jurnal Zootek 32(5):1-10.

Puspawati, N.M. \& I.N. Simpen. 2010. Optimasi deasetilasi khitin dari kulit udang dan cangkang kepiting limbah restoran seafood menjadi khitosan melalui variasi konsentrasi $\mathrm{NaOH}$. Jurnal Kimia 4(1): 79-90.

Ratriyanto, A. 2018. Pola produksi telur puyuh yang diberi ransum disuplementasi betain dan metionin. Journal of Sustainable Agriculture 33(1):1-7.

Saenab, A., E.B. Laconi, Y. Retnani, \& M.S. Mas'ud. 2010. Evaluasi kualitas pelet ransum komplit yang mengandung produk samping udang. JITV 15(1):3139.

Sahara, E. 2011. Penggunaan kepala udang sebagai sumber pigmen dan kitin dalam pakan ternak. Agrinak. 1(1):31-35.

Sudrajat, D., D. Kardaya, E. Dihansih, \& S.F.S. Puteri. 2014. Performa produksi telur burung puyuh yang diberi ransum mengandung kromium organik. JITV 19(4):257-262 . 